\title{
Thymus species in Ethiopia: Distribution, medicinal value, economic benefit, current status and threatening factors
}

\author{
Destaw Damtie $^{1^{*}}$ and Yalemtsehay Mekonnen² \\ ${ }^{1}$ Biology Department, Bahir Dar University, Ethiopia. \\ ${ }^{2}$ Microbial, Cellular and Molecular Biology Department, Addis Ababa University, Ethiopia.
}

\begin{abstract}
The genus Thymus is one of the genera in the family Lamiaceae. In Ethiopia, it is represented by two endemic species namely Thymus serrulatus and Thymus schimperi. The aims of this study were to identify the types of species from six geographically distant localities in Ethiopia, assess the ethnobotanical and socioeconomic information of these species in these localities and gather information about the current status and threatening factors of these species in the six localities. The plant specimens from these localities were authenticated by experts in the National Herbarium of Addis Ababa University as Thymus serrulatus and Thymus schimperi. The plants were rated by local informants as treatments for ailments like blood pressure $(30.7 \%)$, general pain syndrome $(10 \%)$, influenza $(10 \%)$, abdominal pain $(10 \%)$, ascariasis $(2.9 \%)$, and intestinal parasites $(2.9 \%)$. The informants rated the economic value of these plants as animal forage $(71.5 \%)$, bee forage $(71.5 \%)$, condiments $(68 \%)$, and washing and fumigation $(46 \%)$. According to the informants, the status of Thymus species is declining from time to time due to overgrazing $(80.7 \%)$, agricultural expansion (64.2\%), overharvesting $(48.57 \%)$, uprooting during harvesting $(14.2 \%)$, and lack of recognition $(13.6 \%)$
\end{abstract}

Keywords: Ethiopia, Thymus schimperi, Thymus serrulatus, threatening factors

DOI: http://dx.doi.org/10.4314/ejst.v8i2.3

\section{INTRODUCTION}

The Lamiaceae/Labiatae (WHO, 1999) is a large plant family represented by about 236 genera and above 7200 species (Hedberg et al., 2006). This family is much diverse in terms of ethnomedicine owing to its diverse chemical composition (Niculae et al., 2009) such as flavonoids, phenolic acids, terpenes, saponins, polyphenols, tannins, iridoids, and quinones (Özgen et al., 2011).

The genus Thymus under Lamiaceae is noteworthy for its numerous species and varieties (Boz et al., 2009). In Ethiopia, this genus is represented by two indigenous species namely T. serrulatus and T. schimperi (Jaafari et al., 2007) both of which are locally named as Tosign (Amharic) and Tesni/Thasne (Tigrigna). These species are endemic to Ethiopian highlands (2200-4000 m. a.s.1.) (Sebsebe Demissew and
Nigist Asfaw, 1994) and are restricted to the afromontane and afroalpine zones of the country (IBC, 2008). Thymus schimperi is widely distributed in central, eastern, and northern Ethiopia and T. serrulatus is restricted to northern parts of the country (Sebsebe Demissew and Nigist Asfaw, 1994). However, there are conflicting reports regarding the distributions of these species in Ethiopia. For example, T. serrulatus is reported to be found from Jimma (South West Ethiopia) (Parvez and Yadav, 2008; Mahbere Silassie, Alamata, and Ofla (Tigray, North Ethiopia) (Atey G/Medhin, 2008) and Yilmana Densa (Amhara Region, Norther West Ethiopia) (Collected and identified during this research).

On the other hand, T.schimperi is widely distributed in Amhara, Oromia, and Southern Nations Nationalities and Peoples Regions. It is found in Denkoro For-

\footnotetext{
*Corresponding author:zegades529@yahoo.com

(C) This is an Open Access article distributed under the terms of the Creative Commons Attribution License (http://creativecommons.org/licenses/CC BY4.0)
} 
est (Abate Ayalew, 2013), Chancho (Dibaba Chewaka, 2009), Ankober (Doni et al., 2012), Menz Gera Midir (Guassa) (GAGMP , 2007), Tarma Ber wereda of North Shewa and Gondar areas (Nigist Asfaw et al., 2000).

In Oromia Region, T.schimperi is found in Adaba Dodola area (Kunert, 2000), Dinsho (Ermias Dagne et al., 1998; Ermias Lulekal et al., 2011); Sanetti Mountains (Tariku Mekonnen et al., 2011); Goma (Behailu Etana, 2010), Asendabo (Parvez and Yadav, 2008); areas around Jimma (Jemal Hussien et al., 2011); Debre Zeyit (Mohammed Nasir, 2010), Awash National Park (Tinsae Bahru et al., 2010), and Menagesha Suba State Forest (Abate Zewdie, 2007).

In the different parts of the world, Thymus extracts are traditionally used orally to treat dyspepsia and other gastrointestinal disturbances, bronchitis, pertussis, laryngitis and tonsillitis, and coughs due to colds (Belaqziz et al., 2010; Özgen et al., 2011). Topical applications of thyme extracts have been used in the treatment of minor wounds, the common cold, and disorders of the oral cavity, and as an antibacterial agent in oral hygiene (Özgen et al., 2011).

Traditionally, Thymus species in Ethiopia are used in a variety of forms (Malcolm and Zelalem Tefera, 2007). The fresh or dried leaves of these species are used locally as condiments and tea (Sebsebe Demissew and Nigist Asfaw, 1994); in the preparation of berbere and "shirro" (pepper and bean/pea powder) (Amare Getahun, 1976); for the preparation of Metata ayb (a traditional Ethiopian fermented cottage cheese) (Eyassu Seifu, 2013).

In traditional medicine, Thymus species in Ethiopia are used to treat different illnesses like gonorrhea, cough and liver disease (Kunert, 2000); renal diseases (Andemariam, 2010); Gara Bokoyso (Oromifa) (stomach pain) (Haile Yineger et al., 2008); hypertension (Nigist Asfaw et al., 2000); kidney problem (Behailu Etana, 2010) and dermal fungi (Doni et al.,
2012). They are checked to have antihelimenthic (Jemal Hussien et al., 2011); antibacterial and fungicidal activities (Dibaba Chewaka, 2009; Mohammed Nasir, 2010; Pagiotti et al., 2010; Shewaye Lakew, 2011).

The major constituents of T. schimperi and T. serrulatus in Ethiopia are thymol and carvacrol (Nigist Asfaw et al., 2000). All the pharmacological actions of thyme thus may be due mainly to the phenolic component thymol, which is a major component in their essential oils (Sebsebe Demissew and Nigist Asfaw, 1994). In addition to their medicinal values, Thymus species in Ethiopia have economic uses like animal feed and bee forage (Likawent Yeheyis et al., 2008). The present study thus was designed (1) to identify the types of Thymus species from six distant localities in Ethiopia (2) to collect information about their medicinal values, their economic benefits, their current status and pressures or threatening factors on these species.

\section{METHODS}

\section{Study area}

Samples of Thymus species, ethnobotanical information, socioeconomic data, and threatening factors were collected from six localities of Ethiopia (Figure 1). These localities were Ofla and Alamata woredas (districts) of South Tigray (Tigray Region); Yilmana Densa woreda of West Gojjam (Amhara Region); Mojana woreda of North Shewa (Amhara Region); Meskena Mareko woreda of Gurage (Southern Nations, Nationalities and Peoples Region); and Sinana Dinsho woreda ( Oromia region).

The specific areas for plant collection were: (1) Menkere (Ofla, South Tigray) $625 \mathrm{Kms}$ North of Addis Ababa (Capital city of Ethiopia); Akojira (Alamata, Southern Tigray) $605 \mathrm{Kms}$ North of Addis Ababa; Bir Adama mountain (Yilmana Densa, West Gojjam) 443 Kms North west of Addis Ababa; Tarma Ber (Mojana woreda, North Shewa) 190 Kms North east of Addis Ababa; Zebidar Mountain (Meskena 
Mareko woreda, Southern Nations Nationalities and Peoples Region) $135 \mathrm{Kms}$ South west of Addis Ababa; and Dinsho (Bale Mountains National park, Oromia Region) which is $370 \mathrm{Kms}$ away from Addis Ababa through Assela (Figure 1).

Ofla woreda has an altitudinal range of 1800-2440 $\mathrm{m}$. Its mean annual rainfall is between $700-800 \mathrm{~mm}$ with mean daily temperatures ranging from 10-22 ${ }^{\circ} \mathrm{C}$. Rainfall is bimodal; a short rainy season "belg" between February and May, and a long rainy season "meher" between June and September. Mixed crop-livestock production is the major activity of the farming system. Wheat, maize, barley, faba bean and sorghum are the major crops grown. The major livestock types reared in the district are cattle, sheep and chicken. Donkeys, goats and honeybees are also reared having lower shares (Girmay Tesfay et al., 2014).
Alamata woreda has an altitudinal range of 1178 to $3148 \mathrm{~m}$ a.s.1 of which and $75 \%$ is low land $(1500 \mathrm{~m}$ a.s.1 or below) and $25 \%$ intermediate highlands (between 1500 and $3148 \mathrm{~m}$ a.s.1). Eutric Vertisols, Lithic Leptosols (Cambic) and Lithic Leptosols (Orthic) are the soil types covering nearly $100 \%$ of the land in the woreda (IPMS, 2005). The annual temperature ranges between $14.6{ }^{\circ} \mathrm{c}$ and $29.7^{\circ} \mathrm{c}$ (Dawit Gebregziabher, 2010). Alamata has bimodal rainfall patterns; the belg (short rains) (from January to February) and the Meher (long rains) (from July to August). The mean annual rainfall of the area is around $963.5 \mathrm{~mm}$. Teff and sorghum are the dominant crops covering $75 \%$ of the woreda caltivated area. Currently field pea, faba bean, lentils (in high land) teff and pepper (in low land) are the most important marketable commodities in the woreda. Livestock production in the woreda involves cattle, sheep, goats, camel, poultry and bee production (IPMS, 2005; Dawit Gebregziabher, 2010).

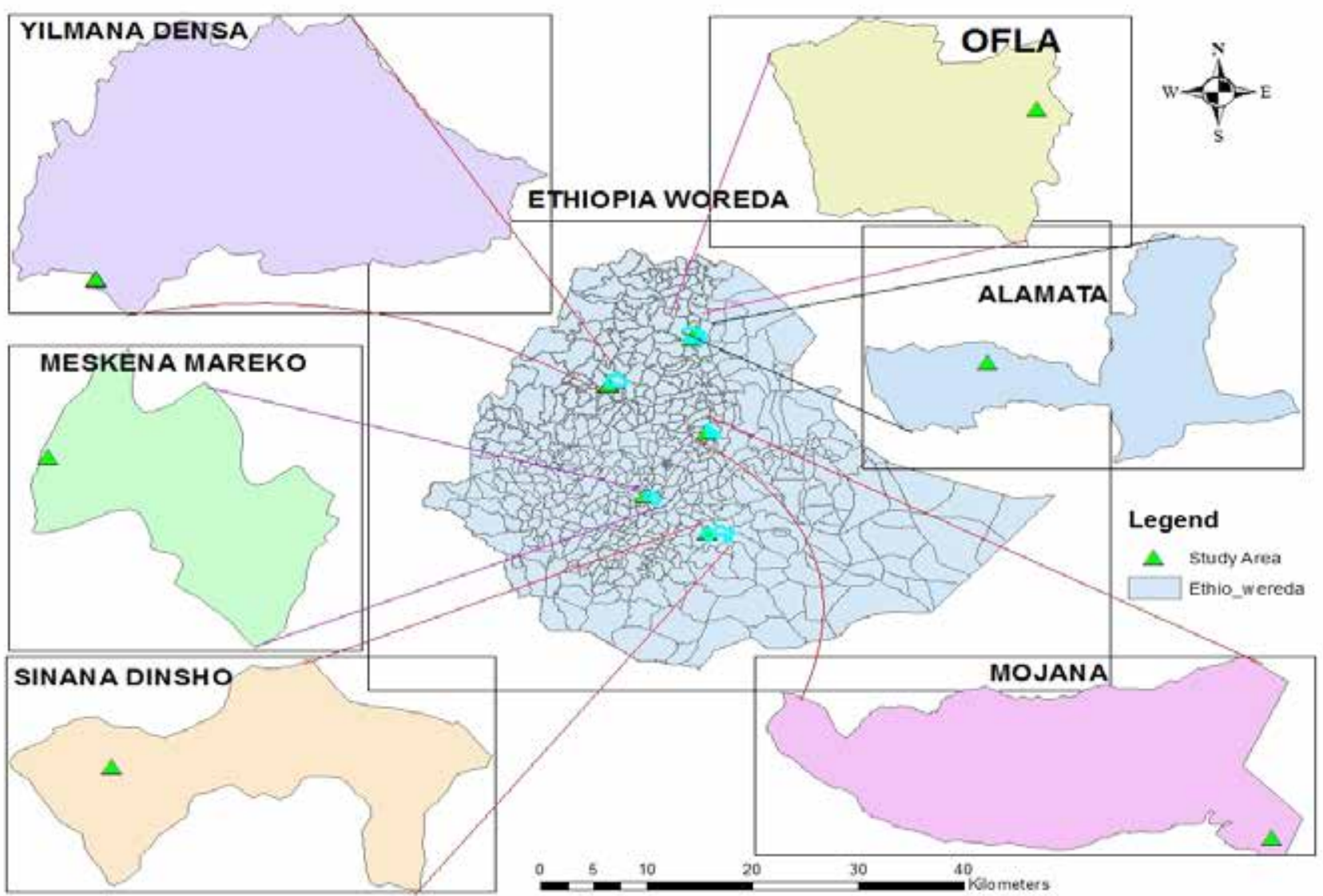

Figure 1: Data/Sample Collection Sites of Thymus species for the present study (constructed from GPS data) 
Yilmana Densa woreda is one of the fifteen woredas of West Gojjam Administrative zone. Its capital town, Adet is found $42 \mathrm{~km}$. from Bahir Dar on the south and $443 \mathrm{~km}$ from Addis Ababa through Mota. The average annual temperature ranges between $8.8^{\circ} \mathrm{c}-25.2^{\circ} \mathrm{c}$, and the average annual rainfall ranges between 1100-1270 mms. The woreda has three types of soil: red (65\%), brown (15\%) and black (20\%). Favorable climatic condition and fertile soil makes the woreda suitable for crop production and livestock husbandry. In the woreda, the rural people depend on crop production and livestock husbandry for their Livelihood. Cropping is predominantly rain fed. As part of mixed farming, the woreda possesses cattle, sheep, goats, equine poultry and bee hives. This woreda is one of the major maize producers followed by Teff, Barley and Wheat (Solomon Abie, 2011).

Tarmaber is located $190 \mathrm{~km}$ away from Addis and covers about 54,000 ha of lands. Agro climatologically $17 \%$ of the land is lowland, 28 $\%$ semi-arid (Woinadega) and $54.7 \%$ is highland (Dega). Its altitude is ranging from 1500 to 3100 meter above sea level. The average annual temperature and the mean monthly rain fall are about $15.5^{\circ} \mathrm{C}$ and $1200 \mathrm{~mm}$ respectively. The topography is dominated by chain of hills and rouged mountains; thereby $15.28 \%$ of the woreda is mountainous, 32.78 $\%$ is plain lands, $6.29 \%$ valleys and $45.65 \%$ are rugged types (http://edaethiopia.org/index.php/wherewe-work/amhara/tarma-ber).

Meskana Mareko is a district located in the Gurage zone, Southern Nations, Nationalities, and People's Regional state (SNNPR) $135 \mathrm{~km}$ south of Addis Ababa. The dominant ethnic group is Gurage of meskan dialects. Farming is the main economic activity and the main cash crops are pepper, coffee and khat. The woreda lies at an average altitude of
$1900 \mathrm{~m}$ above sea level, ranging from $1750 \mathrm{~m}$ a.s.l in the lowlands to $3400 \mathrm{~m}$ a.s.1 in the mountains. Annual rainfall in Meskana Mareko area ranges between 700$1870 \mathrm{~mm}$. Although the main rainy season is from June to September, light rains are common around March and April. The warmest months are between January and June with a maximum temperature of $30.4{ }^{\circ} \mathrm{C}$ in March during the last ten years. During the last decade the annual mean maximum temperature was $26.3{ }^{\circ} \mathrm{C}$ and minimum mean temperature was $11.1^{\circ} \mathrm{C}$ (Solomon Tesfaye et al.,2012).

Dinsho Woreda is one of the districts in Oromia Region. Dinsho is located at the northern edge of the Bale Mountains National Park (BMNP) $370 \mathrm{Kms}$ South East from Addis Ababa. It has altitudinal ranges from 2441-3600 m a.s.l. (Haile Yineger et al., 2008). Its mean annual temperature and rainfall are $10.26^{\circ} \mathrm{C}$ and $1218.64 \mathrm{~mm}$ respectively (Haile Yineger et al., 2008). The trend of the rainfall distribution is bimodal namely "belg" (small rains occurring from February to May) and "kiremt" (big rains occurring from August to October) (Luizza et al., 2013). Dinsho's loamy, fairly fertile, and low-density Mollic Andosol soils are results of extended weathering of lava outflows stemming from the Oligocene Epoch (33.9 - 23 million years B.P.) (Luizza et al., 2013). It has a typical vegetation type of undifferentiated Afromontane forests. The predominant inhabitants are the Oromo people who use economic activities primarily based upon mixed farming that involves pastoralism and cultivation of crops such as wheat and barley (Haile Yineger et al., 2008).

\section{Data collection}

This information about $T$. serrulatus and $T$. schimperi species were collected from informants using semi-structured questionnaires. The development 
agents (DAs) in each study site were involved in the informant selection and data collection processes. The informants in each study site were farmers who had meetings with the DAs. A total of 140 male informants were randomly selected and asked about the medicinal value, economic advantage, current status, and threatening factors of Thymus species in their localities. Data collection took place from $28^{\text {th }}$ July through $28^{\text {th }}$ September 2013.

\section{Plant material identification}

Samples of the aerial parts of Thymus species were collected from $28^{\text {th }}$ July through $28^{\text {th }}$ September 2013 from the above mentioned districts and regions. The collected specimens were pressed and taken to National Herbarium of Addis Ababa University for authentication. They were identified by Mr. Melaku Wondafrash in the National Herbarium of Addis Ababa University. After identification, voucher specimens were deposited in the Natural Herbarium of Addis Ababa University with voucher numbers Ala-2013 (Thymus from Alamata district), But-2013 (Thymus from Butajira, Meskana Mareko woreda), Bal-2013 (Thymus from Dinsho, Bale Mountains National Park), Ofl-2013 (Thymus from Ofla district), Tar-2013 (Thymus from Tarma Ber, Mojana district) and Yil2013 (Thymus from Yilmana Densa district).

\section{RESULTS}

Identified Thymes species collected from six

\section{localities in Ethiopia}

Out of the Thymus species collected from six localities, three of them (Ofl-2013, Ala-2013, and Yil-2013) were identified as T. serrulatus and the rest three (Tar2013, But-2013, and Bal-2013) as T. schimperi (Table $1)$.

Medicinal value of $T$. schimperi and $T$. serrulatus from Ethiopia

The majority of the respondents $43(30.7 \%)$ have at least heard about the use of Thymus species as a treatment for blood pressure although a lot of them $33(23.5 \%)$ have no information about the health significances of these species. On the other hand, $52(30 \%)$ of the respondents have mentioned that these plants have applications to treat general pain syndrome, influenza and abdominal pain (Table 2). Some respondents from Tgray Region mentioned the ascaricidal $4(2.9 \%)$ and intestinal paraciticidal $4(2.9 \%)$ effects of $T$. serrulatus grown in Tigray. In almost all the localities, the respondents mentioned that it is the aerial parts of $T$. schimperi and $T$. serrulatus which are dried, crushed, made into tea and taken orally to treat the ailments mentioned.

Table 1. Thyme species identified from six localities

\begin{tabular}{lcl}
\hline \multicolumn{1}{c}{ S.No. } & Voucher No. ${ }^{\lambda}$ & \multicolumn{1}{c}{ Identified as the species } \\
\hline 1 & Ofl-2013 & Thymus serrulatus \\
2 & Ala-2013 & Thymus serrulatus \\
3 & Yil-2013 & Thymus serrulatus \\
4 & Tar-2013 & Thymus schimperi \\
5 & But-2013 & Thymus schimperi \\
6 & Bal-2013 & Thymus schimperi
\end{tabular}

${ }^{\lambda}$ Ofl- T.serrulatus from Ofla, Ala- T.serrulatus from Alamata, Yil- T.serrulatus from Yilmana Densa, Tar- T. schimperi from Tarmaber, But- T.schimperi from Butajira, Bal- T.schimperi from Bale. 
Table 2. Human ailments reported to be treated by $T$. schimperi and T. serrulatus

\begin{tabular}{|c|c|c|c|c|c|c|c|c|c|}
\hline $\begin{array}{l}\text { Human } \\
\text { Disease }\end{array}$ & $\begin{array}{l}\text { Scientific } \\
\text { name }\end{array}$ & Family & Local name* & $\begin{array}{c}\text { Voucher }^{\lambda} \\
\text { No. }\end{array}$ & $\begin{array}{l}\text { Part } \\
\text { used }\end{array}$ & $\begin{array}{c}\text { Form } \\
\text { used }\end{array}$ & $\begin{array}{l}\text { Methods of } \\
\text { preparation }\end{array}$ & $\begin{array}{l}\text { Route } \\
\text { of } \\
\text { admin- } \\
\text { istration }\end{array}$ & $\begin{array}{c}\text { Respon- } \\
\text { dents }\end{array}$ \\
\hline & $\begin{array}{c}\text { T. schipmeri } \\
+ \\
\text { T. serrulatus }\end{array}$ & Lamiaceae & $\begin{array}{l}\text { Tosign (Amh), } \\
\text { Toshigne (Gur), } \\
\text { Tosigni (Oro) } \\
\text { Teshne (Tig) }\end{array}$ & $\begin{array}{l}\text { Ofl-2013, Ala- } \\
\text { 2013, Yil-2013, } \\
\text { Tar-2013, But- } \\
\text { 2013, Bal-2013 }\end{array}$ & & & & & \\
\hline $\begin{array}{l}\text { Blood } \\
\text { pressure }\end{array}$ & & ،, & ،, & ،, & $\begin{array}{l}\text { Leaves } \\
\text { and } \\
\text { flowers }\end{array}$ & Dried & $\begin{array}{l}\text { Crushed and } \\
\text { drunk as tea }\end{array}$ & Oral & $\begin{array}{l}43 \\
(30.7 \%)\end{array}$ \\
\hline $\begin{array}{l}\text { General } \\
\text { pain } \\
\text { syndrome }\end{array}$ & ' & , & ،, & ، & $\begin{array}{l}\text { Leaves } \\
\text { and } \\
\text { flowers }\end{array}$ & Dried & $\begin{array}{l}\text { Crushed and } \\
\text { drunk as tea }\end{array}$ & Oral & $14(10 \%)$ \\
\hline Influenza & ' & ', & ، & ', & $\begin{array}{l}\text { Leaves } \\
\text { and } \\
\text { flowers }\end{array}$ & Dried & $\begin{array}{l}\text { Crushed and } \\
\text { drunk as tea }\end{array}$ & Oral & $14(10 \%)$ \\
\hline $\begin{array}{l}\text { Abdominal } \\
\text { pain }\end{array}$ & ', & ،, & ،, & , & $\begin{array}{l}\text { Aerial } \\
\text { parts }\end{array}$ & Dried & $\begin{array}{l}\text { Crushed and } \\
\text { drunk as tea }\end{array}$ & Oral & $14(10 \%)$ \\
\hline Ascariasis & ' & ' & ', & ' & Leaves & Dried & Drunk as tea & Oral & $4(2.9 \%)$ \\
\hline $\begin{array}{l}\text { Intestinal } \\
\text { parasites }\end{array}$ & ', & ، & ، & ', & Leaves & Dried & Drunk as tea & Oral & $4(2.9 \%)$ \\
\hline $\begin{array}{l}\text { I don't } \\
\text { know }\end{array}$ & ', & $>>$ & $>>$ & $>>$ & - & - & - & - & $\begin{array}{l}33 \\
(23.5 \%)\end{array}$ \\
\hline
\end{tabular}

*Amh- Amharic; Gur- Guragigna, Tig- Tigrigna, Oro- Oromipha

${ }^{\lambda}$ Ofl- T.serrulatus from Ofla, Ala- T.serrulatus from Alamata, Yil- T.serrulatus from Yilmana Densa, Tar- T.schimperi from Tarmaber, But- T.schimperi from Butajira, Bal- T.schimperi from Bale.

\section{Economic benefits of $T$. schimperi and T. serrulatus from Ethiopia}

The respondents mentioned the economic uses of Thymus species in Ethiopia as honey bee forage, animal forage, food additives (condiments), and washing and fumigating household utensils such as buckets for milking and dough preparation (Table 3). The respondents further mentioned that such fumigation of milking jars and buckets for putting milk and dough of injera is important to maintain milk and injera with best flavors and without rancidity. According to the respondents, the honey from Thymus species has medicinal value and with special taste. Milk, yogurt, butter, and meat from animals fed with Thymus species have special taste and flavor. In addition, application of Thymus species as food additives increases the flavor and shelf-life of foods and sauces such as shiro, berbere, butter, Besso etc. Furthermore, the respondents have mentioned that Thymus as an animal forage is useful for fattening. Furthermore fumigating the honey beehives attracts honey bees and eliminates honey bee diseases as was raised by the respondents from Southern Tigray. During interview with the respondents, it was clear that more people from other areas of the country use Thymus species as food additives than people in Southern Tigray. The people in Tigray know that it can be used as tea but most of them do not use it. 
Table 3. Report on other economic uses of T. schimperi and T. serrulatus

\begin{tabular}{|c|c|c|c|c|c|}
\hline Scientific name & Family & $\begin{array}{l}\text { Local * } \\
\text { name }\end{array}$ & $\begin{array}{c}\text { Voucher }^{\lambda} \\
\text { No. }\end{array}$ & $\begin{array}{c}\text { Economic } \\
\text { Use }\end{array}$ & Respondents \\
\hline T. schimperi + T. serrulatus & Lamiaceae & $\begin{array}{l}\text { Tosign (Amh), } \\
\text { Toshigne (Gur), } \\
\text { Tosigni (Oro) } \\
\text { Teshne (Tig) }\end{array}$ & $\begin{array}{l}\text { Ofl-2013, Ala-2013, } \\
\text { Yil-2013, Tar-2013, } \\
\text { But-2013, Bal-2013 }\end{array}$ & & \\
\hline T. schimperi + T. serrulatus & Lamiaceae & ' & "' & Bee forage & $100(71.5 \%)$ \\
\hline T. schimperi + T. serrulatus & Lamiaceae & ', & ", & Animal forage & $100(71.5 \%)$ \\
\hline T. schimperi + T. serrulatus & Lamiaceae & ' & ', & $\begin{array}{l}\text { Condiment } \\
\text { (additive to shiro, } \\
\text { berbere, butter, } \\
\text { Besso) }\end{array}$ & $95(68 \%)$ \\
\hline T. schimperi + T. serrulatus & Lamiaceae & ', & ", & Drink (tea) & $95(68 \%)$ \\
\hline T. schimperi + T. serrulatus & Lamiaceae & ', & ', & $\begin{array}{l}\text { Washing and } \\
\text { fumigating jars for } \\
\text { milking and buckets } \\
\text { for putting paste of } \\
\text { injera }\end{array}$ & $65(46 \%)$ \\
\hline
\end{tabular}

*Amh- Amharic; Gur- Guragigna, Tig- Tigrigna, Oro- Oromipha

${ }^{\lambda}$ Ofl- T.serrulatus from Ofla, Ala- T.serrulatus from Alamata, Yil- T.serrulatus from Yilmana Densa, Tar- T.schimperi from Tarmaber, But- T.schimperi from Butajira, Bal- T.schimperi from Bale.

\section{Current status and threatening factors of Thymus} species from Ethiopia

According to the respondents' responses, Thymus species endemic to Ethiopia (T. schimperi and T. serrulatus) exist as wild species and their current status is decreasing from year to year (Table 4). The major threatening factors for these species were identified to be overgrazing followed by agricultural expansion, overharvesting, harvesting the whole plant including the roots, and lack of recognition. This reduction in Thymus species is high in North
Shewa and Gurage zone due to the mentioned threatening factors. However, the situation is better in Tigray (Alamata and Ofla), Yilmana Densa (West Gojjam) and Dinsho (Bale) since the collection sites are closed from human and animal encroachment. Harvesting the whole plant including the roots is the biggest problem in North Shewa due that the plant is served as an income source for inhabitants there. It is usual to see the youth and women selling the dried plant parts to travelers on the highway from Addis Ababa to North Ethiopia (Wello and Tigray). 
Table 4. Summary table about the occurrence and current status of T. schimperi and T.serrulatus in Ethiopia

\begin{tabular}{|c|c|c|c|c|c|c|}
\hline Scientific name & Family & $\begin{array}{l}\text { Local* } \\
\text { Name }\end{array}$ & Occurrence & $\begin{array}{r}\text { Current } \\
\text { status }\end{array}$ & $\begin{array}{c}\text { Threatening } \\
\text { factors }\end{array}$ & Respondents \\
\hline $\begin{array}{l}\text { T. schimperi }+T \text {. } \\
\text { serrulatus }\end{array}$ & Lamiaceae & $\begin{array}{l}\text { Tosign (Amh), } \\
\text { Toshigne (Gur), } \\
\text { Tosigni (Oro) } \\
\text { Teshne (Tig) }\end{array}$ & wild & & & \\
\hline ' & ' & ' & ' & Decreasing & Overharvesting & $68(48.57 \%)$ \\
\hline ', & ', & , & ", & Decreasing & Overgrazing & $113(80.7 \%)$ \\
\hline ، & ', & ', & ،, & Decreasing & $\begin{array}{l}\text { Lack of } \\
\text { Recognition }\end{array}$ & $19(13.6 \%)$ \\
\hline ', & ', & ', & ', & Increasing & $\begin{array}{l}\text { Due to its high } \\
\text { seed production }\end{array}$ & $2(1.4 \%)$ \\
\hline ', & ', & ، & ،, & Decreasing & $\begin{array}{l}\text { Agricultural } \\
\text { expansion }\end{array}$ & $90(64.2 \%)$ \\
\hline ', & ', & ', & ', & Decreasing & $\begin{array}{l}\text { Harvesting the } \\
\text { whole plant } \\
\text { including the } \\
\text { roots }\end{array}$ & $20(14.2 \%)$ \\
\hline
\end{tabular}

*Amh- Amharic; Gur- Guragigna, Tig- Tigrigna, Oro- Oromipha

\section{DISCUSSION}

While Thymus specimens collected from the Northern parts of Ethiopia (Tigray and Gojjam) were found to be T. serrulatus, those collected from central (Shewa) and Southern (Bale and Butajira) were T. schimperi. This agrees with the reports of (Sebsebe Demissew and Nigist Asfaw, 1994; Nigist Asfaw et al., 2000). The medicinal value of Thymus serrulatus and Thymus schimperi were identified by the respondents as; to treat blood pressure, to treat general pain syndrome, influenza, abdominal pain, and to treat intestinal parasites like ascaris. Literature supports these bioactivities of Thymus species. For example the work by Miloradovic et al. (2010) showed that thyme extract (TE- T. serpyllum L.) resulted in a significantly reduced level of Systolic Atrial Pressure (SAP) and Diastolic Atrial Pressure (DAP) in hypertensive rats. In addition, T. vulgaris was found to reduce pain in mice while applying to plate, tail flick and formalin tests (Taherian et al., 2009). So it is not surprising if T. serrulatus and T. schimperi act as treatments for general pain syndrome. Essential oils of thyme are also known for their antivirus, antibacterial, antifungal and antiworm activities owing to their active component thymol (Lezak, 2000). This may be the reason why T. serrulatus and T. schimperi are used for treating intestinal parasites and abdominal pain. Furthermore, thymol is the major component of Thymus species from Ethiopia. For example the works of Ermias Dagne et al. (1998) and Nigist Asfaw et al. (2000) revealed that the components of $T$. schimperi were by large thymol $50 \%$ and more than $30 \%$, respectively. In addition, the abdominal pain reliving capacity of these plants may be due to their abilities to kill $\mathrm{He}$ licobacter pylori (Esmaeili et al., 2012) and their anti-acidic nature.

The respondents mentioned the economic value of $T$. serrulatus and T. schimperi as honey bee forage, animal forage, food additives, drinks as tea and washing and fumigation of jars for milking and baking. This agrees with the work by Tewodros Eshete et al. (2013), showing that food supplements with thyme mix improve intake, digestibility, daily weight 
gain, final body weight, empty body weight, hot carcass weight, and dressing percentage compared to non-supplemented group and improves the sensory quality of sheep meat. Furthermore, thyme honey has medicinal values. For example, the work by Tsiapara et al. (2009) showed that thyme honey reduces the viability of prostate cancer cell line (MCF-7). Thus, the information from the informants is valuable.

According to the informants, the status of $T$. serrulatus and T. schimperi is declining mainly due to overgrazing followed by agricultural expansion, overharvesting, harvesting the whole plant including the roots, and lack of recognition. The threatening factors for these plants are similar to those identified by $\mathrm{Ka}$ layu Mesfin et al. (2013). Harvesting the whole plant including the root continuously is a dangerous practice which interferes with the life cycle of the species and results in eradication of the whole plant (Wangchuk et al., 2008). These plants are restricted to limited geographical regions (Alpine and Afroalpine) so that degradation of these areas may result in degradation of the whole species. Overgrazing of $T$. serrulatus and T. schimperi is a big challenge owing to their suitability as forages for cattle, sheep and goats as well as the beliefs of inhabitants that animals which fed these plants give tasty meat, mutton, and milk. The other problem is commercialization of these wild species without conserving them (Zuzarte et al., 2011). This may be due to the reason that wild species are communal and no one cares about them as private (cultivated) species. Their multiple use as condiments, forage, medicinal value, and tea increased the harvesting pressure on these plants and they are continuously declining. In the same way all these pressures may be indirectly caused by human population expansion and increased level of unemployment rate (Wangchuk et al., 2008). In addition, there is continuous and bulk requirement of these herbs. To supply such large quantity of the herbs, large scale cultivation would be required, which in turn will generate good business opportunities and human resource development (Tripathi et al., 2009).

\section{CONCLUSIONS}

The specimens of Thymus collected from Southern Tigray (Alamata and Ofla) as well as from West Gojjam (Yilmana Densa) were found to be T. serrulatus while those collected from Tarma Ber, Buta Jira, and Bale were T. schimperi. Many of the informants agreed about the importance of these species to treat blood pressure followed by general pain syndrome, influenza, abdominal pain, and intestinal parasites like Ascaris in descending order. However great majority of them especially those from Tigray do not know about the medicinal uses of these plants. Economically, these plants are important sources of animal and honey bee forage, serve as condiments, tea, and fumigants. Despite their medicinal and economic uses, these plants are highly diminishing due to overharvesting, overgrazing, agricultural expansion, whole plant harvesting including the roots, and lack of recognition.

\section{REFERENCES}

Abate Ayalew. (2013). Floristic Composition and Structural Analysis of Denkoro Forest, South Wello. MSc thesis, Addis Ababa University, Ethiopia.

Abate Zewdie. (2007). Comparative Floristic study on Menagesha Suba State Forest on Years 1980 and 2006. MSc Thesis, Addis Ababa University, Ethiopia.

Amare Getahun. (1976). Some Common Medicinal and Poisonous Plants Used in Ethiopian Folk Medicine. REGISTRATED IN THE DATA BANK PRELUDE ; REF : VG 07.

Andemariam, S.W. (2010). Legislative Regulation of Traditional Medicinal Knowledge in Eritrea vis-àvis Eritrea's Commitments under the Convention on Biological Diversity: Issues and Alternatives. Law, Environment and Development Journal 6(2): 133-162. 
Atey G/Medhin. (2008). Local use of spices, condiments and non-edible oil crops in some selected woredas in Tigray, Northern Ethiopia. MSc Thesis, Addis Ababa University, Ethiopia.

Behailu Etana. (2010). Ethnobotanical Study of Traditional Medicinal Plants of Goma Wereda, Jima Zone of Oromia Region, Ethiopia. MSc thesis, Addis Ababa University, Ethiopia.

Belaqziz, R., Harrak , R., Romane, A., Oufdou, K and ElFels, M.A.E. (2010). Antimicrobial and Insecticidal Activities of the Endemic Thymus broussonetti Boiss and Thymus maroccanus Ball. Journal of Natural Products 4(4): 230-237.

Boz, I., Burzo, I., Zamfirache, M.M., Toma, C and Padurariu, C. (2009). Glandular and essential oil composition of Thymus pannonicus All. (Lamiaceae). Analele Universitatii din Oradea, Fascicula Biologie XVI (2): 36-39.

Dawit Gebregziabher. (2010). Market Chain Analysis of Poultry: The Case of Alamata and AtsbiWonberta woredas of Tigray Region. MSc thesis, Haramaya University, Ethiopia.

Dibaba Chewaka. (2009). Growth inhibition of grain spoilage fungi by some herb and spice essential oils grown in Ethiopia. MSc thesis, Addis Ababa University, Ethiopia.

Doni, N., Asticcioli, S., Baraldo, M., Tirillini, B., Lulekal, E and Murgia, V. (2012). Researching accessible and affordable treatment for common dermatological problems in developing countries. An Ethiopian experience. International Journal of Dermatology 51: 790-795.

Ermias Dagne, Solomon Hailu, Daniel Bisrat and Tadele Worku. (1998). Constituents of the Essential Oils of Thymus schimperi. Bulletin of the Chemical society of Ethiopia 12(1): 79-82.

Ermias Lulekal, Zemedie Asfaw, Ensermu Kelbessa and Damme, P.V. (2011). Wild edible plants in Ethiopia: a review on their potential to combat food insecurity. Afrika Focus 24 (2): 71-121.

Esmaeili, D., Mobarez, A.M. and Tohidpour, A. (2012). Anti-Helicobacter pylori activities of shoya powder and essential oils of Thymus vulgaris and Eucalyptus globulus. The Open Microbiology Journal 6: 65-69.

Eyassu Seifu. (2013). Chemical composition and microbiological quality of Metata Ayib: a traditional Ethiopian fermented cottage cheese. International Food Research Journal 20(1): 9397.

GAGMP (Guassa Area General Management Plan): General Management Plan 2007-2012 (2007). The community-managed Guassa Area Menz. Compiled and edited, with the support of the Amhara National Regional State, by Frankfurt Zoological Society.

Girmay Tesfay, Girmay Gebresamuel, Alem Gebretsadik, Abrhaley Gebrelibanos, Yemane Gebremeskel and Tesfay Hagos (2014). Participatory Rural Appraisal Report: Ofla woreda, Tigray Region. CASCAPE technical report.

Haile Yineger, Ensermu Kelbessa, Tamirat Bekele and Ermias Lulekal (2008). Plants used in traditional management of human ailments at Bale Mountains National Park, Southeastern Ethiopia. Journal of Medicinal Plants Research 2(6): 132-153.

Hedberg, I., Ensermu Kelbessa, Edwards, S., Sebsebe Demissew and Persson, E. (2006) (eds.). Flora of Ethiopia and Eritrea 5: 553-554.

http://edaethiopia.org/index.php/where-we-work/ amhara/tarma-ber (accessed July11, 2015).

Improving productivity and market success (IPMS, 2005). Alamata Pilot Learning Site Diagnosis and Program Design.

Institute of Biodiversity Conservation (IBC, 2008). Ethiopia: Second Country Report on the State of PGRFA to FAO. 
Jaafari, A., Mouse, A., Rakib, HE-M., Ait M'barek, L., Tilaoui, M., Benbakhta, C., Boulli, A., Abbad, A and Zyad, A (2007). Chemical composition and antitumor activity of different wild varieties of Moroccan thyme. Brazilian Journal of Pharmacognosy 17(4): 477-491.

Jemal Hussien, Chalachew Teshale and Jemal Mohammed (2011). Assessment of the Antimicrobial Effects of Some Ethiopian Aromatic Spice and Herb Hydrosols. International Journal of Pharmacology 7(5): 635-640.

Kalayu Mesfin, Gebru Tekle and Teklemichael Tesfay (2013). Assessment of Threatening Factors of Medicinal Plant Species in Samre District, SouthEastern Tigray, Northern Ethiopia. Journal of Medicinal Plants Studies 1(4): 38-42.

Kunert, M. (2000). Integrated Forest Management Project Adaba-Dodola (IFMP). Deutsche Gesellschaft für Technische Zusammenarbeit (GTZ) GmbH.

Lezak, M. (2000). Herbal Antimicrobials for Intestinal Infections. ANSR-Applied Nutritional Science Reports. Advanced Nutrition Publications, Inc.

Likawent Yeheyis, Aschalew Tsegahun, Ameha Sebsibe, Tefera Mekonen, Nake Ziku and Agraw Amane (2008). Identified indigenous feed resources and their nutritive value in Menz-Gera district of Amhara Region. In Proceedings of the 3rd Annual Regional Conference on Completed Livestock Research Activities, pp. 1-10, Addis Ababa, Ethiopia.

Luizza, M.W., Young, H., Kuroiwa, C., Evangelista, P., Worede, A., Bussmann, R.W and Weimer, A. (2013). Local knowledge of plants and their uses among women in the Bale Mountains, Ethiopia. Ethnobotany Research and Applications 11: 315339.

Malcolm, J.R and Zelalem Tefera (2007). Conservation of Afroalpine Areas. The Ethiopian Wolf, Status
Survey, and Conservation Action Plan, pp. 61-63.

Miloradovic, Z., Bugarski, B., Komes, D., Milanovic, J.G., Ivanov, M., Jovovic, D.J and IhailovicStanojevic, N. (2010). Thyme extract improves blood pressure and oxidative stress in spontaneously hypertensive rats. Journal of Hypertension 28: 156.

Mohammed Nasir. (2010). The antmicrobial effect of essential oils on dermatophytes. MSc thesis, Addis Ababa University, Ethiopia.

Niculae, M., Spinu, M., Sandru, C.D., Brudasca, F., Cadar, D., Szakacs, B., Scurtu, I., Bolfa, P and Mates, C.I. (2009). Antimicrobial potential of some Lamiaceae essential oils against animal multiresistant bacteria. Lucrari Stiinufice Medicina Veterinara XLII (1): 170-175.

Nigist Asfaw, Storesund, H.J., Skattebol, L., Tonnesen, F and Aasen, A.J. (2000). Volatile oil constituents of two Thymus species from Ethiopia. Flavour and Fragrance Journal 15: 123-125.

Özgen, U., Mavi , A., Terzi, Z., Kazaz, C., Asçı, A., Kaya, Y and Seçen, H. (2011). Relationship between chemical structure and antioxidant activity of luteolin and its glycosides isolated from Thymus sipyleus subsp. sipyleus var. sipyleus. Records of Natural Products 5(1): 12-21.

Pagiotti, R., Angelini, P., Rubini, A., Tirillini, B., Granetti, B and Venanzoni, R. (2010). Identification and characterization of human pathogenic filamentous fungi and susceptibility to Thymus schimperi essential oil. Mycoses 54: e364-e376.

Parvez, N and Yadav, S. (2008). Ethnopharmacology of single herbal preparations of medicinal plants in Asendabo district, Jimma, Ethiopia. Indian Journal of Traditional Knowledge 9(4): 724-729.

Sebsebe Demissew and Nigist Asfaw. (1994). Some sseful indigenous labiates from Ethiopia. Lamiales Newsletter 3: 5-6. 
Shewaye Lakew. (2011). Antifungal Substances from Essential Oils. MSc thesis, Addis Ababa University, Ethiopia.

Solomon Abie. (2011). Analysis of the Performance of Local Hybrid Maize Seed Production and Marketing in Marwoled and Goshyie, Womberma and Yilmandensa woreda, Amhara, Ethiopia. MSc thesis, Mekele University, Ethiopia.

Solomon Tesfaye, Yeshambel Belyhun, Takele Teklu, Girmay Medhin, Tesfaye Mengesha, Beyene Petros. (2012). Malaria pattern observed in the highland fringe of Butajira, Southern Ethiopia: a ten-year retrospective analysis from parasitological and metrological data. Malaria World Journal 3(5): 1-8.

Taherian, A.A., Babaei, M., Vafaei, A.A., Jarrahi, M., Jadidi, M and Sadeghi, H. (2009). Antinociceptive effects of hydroalcoholic extract of Thymus vulgaris. Pakistan Journal of Pharmaceutical Sciences 22 (1): 83-89.

Tariku Mekonnen, Afework Bekele and Malcolm, J. (2011). Population Estimates and Diet of Stark's Hare (Lepus starcki Petter, 1963) in the Bale Mountains National Park, Ethiopia. Journal of the Ethiopian Wildlife and National History Society (Walia Special Edition on the Bale Mountains), pp. 53-60.

Tewodros Eshete, Solomon Gizaw and Eyassu Seifu. (2013). Effect of inclusion of tossign (Thymus serrulatus) in concentrate mix supplementation on performance and sensory quality of meat of Menz sheep. Tropical Animal Health and Production 45:177-184.

Tinsae Bahru, Zemede Asfaw and Sebsebe Demisew. (2010). Variation of indigenous botanical knowledge versus social characteristics between the Afar and Oromo Nations in and around the Semi-Arid Awash National Park. Ethiopian Journal of Agricultural Science and Technology 2(1): 1-13.
Tripathi, A., Upadhyay, S., Bhuiyan, $\mathrm{M}$ and Bhattacharya, P. (2009). A review on prospects of essential oils as biopesticide in insect-pest management. Journal of Pharmacognosy and Phytotherapy 1(5): 52-63.

Tsiapara, A.V., Jaakkola, M., Chinou, I., Graikou, K., Tolonen, T., Virtanen, V and Moutsatsou, P. (2009). Bioactivity of Greek honey extracts on breast cancer (MCF-7), prostate cancer (PC-3) and endometrial cancer (Ishikawa) cells: Profile analysis of extracts. Food Chemistry 116(3): 702708.

Wangchuk, P., Ugyen and Olsen, A. (2008). Vulnerable Medicinal Plants and the Risk Factors for their Sustainable Use in Bhutan. Journal of Bhutan Studies 19: 66-90.

WHO. (1999). WHO monographs on selected medicinal plants. Geneva.

Zuzarte, M., Gonçalves, M.J., Canhoto, J and Salgueiro, L. (2011). Antidermatophytic activity of essential oils. Science Against Microbial Pathogens: Communicating Current Research and Technological Advances 1: 1167-1178. 